\title{
UNGARISCHE BIBLIOTHEK
}

Für das Ungarische Institut an der Universität Berlin herausgegeben von ROBERT GRAGGER

1.

\section{Ungarisches Privatrecht}

\author{
Von
}

\author{
Anton Almási
}

I. Band

Berlin und Leipzig 1924

Vereinigung wissenschaftlicher Verleger Walter de Gruyter \& Co.

vormals G. J. Göschen'sche Verlagshandlung - J. Guttentag, Verlagsbuchhandlung Georg Reimer - Karl J. Trübner - Veit \& Comp. 